\title{
Government Decentralization and International Government Performance
}

\author{
Rajeev K. Goel \\ Ummad Mazhar \\ Michael A. Nelson \\ Rati Ram
}

CESIFO WORKING PAPER NO. 6013

CATEgORY 1: PUBlic FinANCE

JULY 2016

An electronic version of the paper may be downloaded

- from the SSRN website:

- from the RePEc website:

- from the CESifo website:

wWw.SSRN.com

Www.RePEc.org

www.CESifo-group.org/wp 


\title{
Government Decentralization and International Government Performance
}

\begin{abstract}
Adding to the literature on the effects of government decentralization, this paper uses a large sample of individual responses from more than a hundred countries about public's perceptions of government's performance along various dimensions to study the relative influences of different types of decentralization, including fiscal decentralization, administrative decentralization, federalism, and aggregate decentralization. Our results show that fiscal and administrative decentralization are qualitatively alike in that greater decentralization in each case improves perceptions of the government performance. Federalist states' performance and overall decentralization are viewed somewhat differently. With regard to tax administration particularly, fiscal and administrative forms of government decentralization result in better outcomes than overall decentralization. Finally, service industries and large firms, ceteris paribus, perceived government performance differently.
\end{abstract}

JEL-Codes: H110, H700, K200, K400.

Keywords: fiscal decentralization, administrative decentralization, federalism, aggregate decentralization, government, tax administration, business permits.

\author{
Rajeev K. Goel* \\ Department of Economics \\ Illinois State University, Normal \\ USA - IL 61790-4200 \\ rkgoel@ilstu.edu \\ Michael A. Nelson \\ University of Akron \\ USA - Akron, OH 4432 \\ nelson2@uakron.edu
}

\author{
Ummad Mazhar \\ Forman Christian College University \\ Lahore / Pakistan \\ umadmazhar@gmail.com
}

\author{
Rati Ram \\ Illinois State University \\ Illinois / USA \\ rram@ilstu.edu
}

\footnotetext{
*corresponding author
} 


\section{INTRODUCTION}

The role that decentralized government structures might play in promoting good governance has intrigued policymakers and researchers for some time. On the one hand, decentralized governments are closer to the populace and can better understand and deliver services that are somewhat tailored to specific needs. There is also greater transparency of government actions as citizens can better observe government actions at the local level (the scope of this somewhat being broadened with the e-government services in the cyberspace). On the other hand, there are some drawbacks to decentralization, notably regarding the (in)ability to coordinate the provision of services at various levels of government (see Prud'homme (1995)) and the appropriation of benefits due to spillovers across jurisdictional boundaries (Oates (1972)). Overall, the trend towards decentralization has been promoted by major international organizations (e.g., International Monetary Fund (2009); United Nations (2008) and the World Bank (1999)) and has found favor across many nations in recent years, as noted by Rodriguez-Pose and Gill (2003), Stegarescu (2005) and the World Bank (1999).

Given its numerous possible dimensions, several classifications of government decentralization have been proposed. For instance, as noted in a recent survey by Martinez-Vazquez et al. (2015), government decentralization may be viewed along expenditure/revenue, policy or political dimensions (also see Rodden (2004)). While the expenditure/revenue aspect of decentralization has been most widely studied, overlapping government jurisdictions and institutional complexities make the clear examination of any one dimension difficult. Other aspects also come into play leading to ambiguities in analyses. For instance, a reliable set of answers or sure fire policy prescriptions has failed to evolve due to a number of reasons. First, no two nations (or even regions within a country) are alike and differ in numerous aspects. This poses challenges in terms of applying similar policies across jurisdictions (Should there be $\mathrm{x}$ number of government hospitals for every y population in every jurisdiction? Then, what about tropical regions that are more prone to certain diseases?). Second, there are many aspects to government decentralization that are qualitatively (in terms of delivering the services) and operationally (in terms of setup costs and timelines) different. For instance, physical and administrative decentralizations are legislatively quite time consuming to change, whereas fiscal decentralization is somewhat easily altered. Thus, it is quite difficult to compare the effects of different forms of decentralization. The related measurement issues have been noted by several scholars, including Blume and Voigt (2011), Brueckner (2003), and Stegarescu (2005). ${ }^{1}$

These issues, coupled with the level of aggregation available in most of the extant data, have led to ambiguous findings regarding the effects of decentralization (see Martinez-Vazquez et al. (2015)). The present paper attempts to fill the void in several ways. First, we analyze the effects of different types of decentralization on government performance via a cross-country context. These include fiscal decentralization and federalism, two measures that have been widely used in

\footnotetext{
${ }^{1}$ Also see Knack and Keefer (1995) for a broader perspective.
} 
past literature, and two relatively new indictors proposed by Ivanyna and Shah (2014) "aggregate decentralization" and "administrative decentralization." The latter two measures are designed to mitigate the comparability problems discussed above, especially when cross-country data sets are used.

Second, we consider different dimensions of government performance. These include business manager perceptions as to how government licensing and permits, and taxation (specifically, tax administration) affects their operations. ${ }^{2,3}$ Government performance in the licensing and permits area is especially relevant for the purpose at hand as it is an activity that is typically carried out at the local level (e.g., liquor licenses for bars, zoning permits, etc.), regardless of how much power rests in the hand of local officials. We can assess how greater decision making authority in the hands of local officials affects business perceptions of government performance in this area.

Third, the underlying data draws upon thousands of individual responses regarding perceptions of government services across more than a hundred countries. Thus, we are able to examine how certain widely prevalent government functions are perceived following different types of decentralization. All these aspects enable us to address the role of decentralization in a deeper (using micro-level data) and wider (across various types of decentralization and many nations) manner than previously considered in the literature. Specifically, while some studies in the literature have studied the effects of decentralization on government performance in some areas (see, for example, Adam et al. (2014)), the scope of analysis (both in terms of the decentralization types and the government performance aspects considered) and the consideration of perceptions of government performance by actual users (i.e., business firms) is unique.

Key questions addressed in this research are:

- Are the effects of a government decentralization measure similar across different dimensions of government performance?

- Do different forms of government decentralization affect government performance perceptions differently?

Our cross-national results are based on World Enterprise Surveys of nearly 100,000 individual business owners and top managers in 113 countries. The analysis shows that fiscal decentralization and administrative decentralization are qualitatively alike in that greater decentralization in each case improves perceptions of government performance. Federalist states' performance and overall decentralization are viewed somewhat differently. With regard to tax

\footnotetext{
2 These aspects of government performance can be seen as tied to the broader discussion on the quality of government (see La Porta et al. (1999)).

${ }^{3}$ Another dimension of government performance or institutional quality, namely, the nexus between decentralization and corruption has been studied at length (see, for example, Fisman and Gatti (2002) and Goel and Nelson (2011)).
} 
administration particularly, fiscal and administrative forms of government decentralization result in better outcomes than overall decentralization. We also find that the business manager perceptions are different for service industries and for large firms. Overall, our findings provide useful policy and analytical insights into the effects of various forms of devolution of powers to subnational units, some of which we discuss. We turn next to a discussion of the underlying theory and the literature.

\section{LITERATURE AND THEORETICAL BACKGROUND}

The broader literature on the choice by governments to decentralize operations (and provision of services) can be tied to the work of Oates (1972), Besley and Coate (2003) and Panizza (1999); also see Faguet (2014). In a nutshell, government decentralization can have positive as well as negative effects, thus analyses with greater size and scope of data are required (which this paper attempts to do). On the positive side, decentralization of government functions leads to greater electoral control and greater yardstick competition among competing jurisdictions. On the down side, decentralization reduces scale economies in the provision of government services, creates the potential for mismatch between the spatial incidence of the benefits for government services and the political boundaries, empowers local interest groups to better drive their agendas, and likely makes attracting qualified applicants for government jobs difficult at the local level (see Adams et al. (2014), Prud'homme (1995)).

The literature on the impacts of decentralization has mostly focused on the effects of fiscal decentralization on various indicators of government and macroeconomic performance (see, for example, Adam et al. (2014), Ebel and Yilmaz (2003), Kyriacou and Roca-Sagalés (2011a) and Yeung (2009)), with varying findings sensitive to the data and methodology employed (see Yeung (2009)). A few studies examine alternate or multiple forms of decentralization (see Fan et al. (2009), Goel and Nelson (2011), Goel and Saunoris (2015), Kyriacou and Roca-Sagalés (2011b), Nelson (2013) and Rodriguez-Pose and Ezcurra (2011)). Fan et al. (2009) found that in nations with a larger number of administrative tiers of government and (given local revenues) a larger number of local public employees, corruption was more prevalent. On the other hand, when local or central governments received a larger share of GDP in revenue, corruption was less prevalent. In another take in a cross-national context, Goel and Saunoris (2015) compare the relative effects of virtual and physical (or number of government tiers) decentralization in terms of their mitigating effects on corruption and the shadow economy. They find virtual decentralization to be relatively more effective. Goel and Nelson (2011) on the other hand, focused on the effects of decentralization across states in the United States, distinguishing between general-purpose and special-purpose governments. They found that while more generalpurpose governments contributed to corruption, the effect of special-purpose governments was mixed. In contrast to these three studies which examine the effects on corruption, RodriguezPose and Ezcurra (2011) study the impact on economic growth for 21 OECD countries, considering fiscal, political and administrative decentralization (measured from sources 
discussed in the paper). Their findings show a negative relation between fiscal decentralization and economic growth. In contrast, the impact of political and administrative decentralization on economic growth is weaker and sensitive to how political decentralization is measured. In yet another angle on the impact of decentralization, Kyriacou and Roca-Sagalés (2011b), study the relation between fiscal and political decentralization and government quality. The authors find that fiscal decentralization improves government quality, but not if such decentralization is accompanied by political decentralization.

Thus, while Rodriguez-Pose and Ezcurra (2011) consider multiple forms of decentralization as the present paper (also see a recent survey by Martinez-Vazquez et al. (2015)), there are several important differences. Specifically, (a) the focus of the present work is on government performance, rather than economic growth; (b) the sample of countries covered here is much broader than OECD and includes both developed and developing nations; (c) the data employed is based on a large number of micro-level observations rather than aggregate country level; and (d) we employ indices of decentralization, which might alleviate the measurement sensitivity issues noted in previous research.

\section{MEASURING GOVERNMENT PERFORMANCE AND DECENTRALIZATION}

Since they are central focus of the paper, we provide some details of how we will measure government performance and decentralization in the analysis that follows.

Government Performance. Various economic and political impacts of decentralization are noted in an editorial by Lago-Peñas et al. (2011) among others. Here we address the impacts or consequences of decentralization from a different perspective than has been considered heretofore, specifically the link between decentralization and business leader perceptions of government performance as it relates to running their business.

The data are drawn from firm-level responses and come from World Enterprise Surveys (WES) of individual business owners and top managers of 94,000 firms in 135 countries (http://www.enterprisesurveys.org/). The WES is a comprehensive annual survey that asks managers about the various aspects of local business environment. ${ }^{4}$ This research focuses on data from 2006 onwards, as it is only after this year that a standardized methodology and instrument

\footnotetext{
${ }^{4}$ A related measure of the private sector business conditions is World Bank's Doing Business (DB) Survey, which uses expert opinions and interviews for the purpose. The DB survey has already acquired wide currency among students of political economy. However, it is fundamentally different from the WES with the latter enjoying important advantages, as shown at length in Hallward-Driemeier and Pritchett (2015). In particular, the DB Survey, being based on expert opinions, implicitly assumes that firms are complying with the rules and regulations of the country of their location. This is not the case with WES. In other words, WES provides the de facto state of the business and legal environment in which firms are operating while DB Survey focuses on de jure state.
} 
sets are used for the survey. ${ }^{5}$ The usable number of countries in our analysis is 113 because we have to match WES countries with the decentralization (or dependent) variables in our analysis.

Given the breadth of issues covered in the WES, we focus only on the subset of questions that asks firms about their relation with the government. We consider two important factors surrounding government-business relations, specifically how tax administration (TaxAdmin), and business licensing and permits (BusLicense) affect the current operation of their establishment. ${ }^{6,7}$

The survey asks respondents or business firms about their first hand impressions of various aspects of government performance. Respondents were asked to pick one of five dimensions of government performance: whether that dimension of performance was viewed as (i) no obstacle; (ii) minor obstacle; (iii) moderate obstacle; (iv) major obstacle; or (v) very severe obstacle. WES coded these responses on a 5 -point scale where $0=$ no obstacle and $4=$ very severe obstacle. To facilitate interpretation of the findings, we collapsed these five dimensions into three labelled as minor obstacle, moderate obstacle and major obstacle. See the Appendix Table A1 for further information on the details of this reclassification scheme.

The two government outcome variables considered in this analysis - TaxAdmin, and BusLicense are somewhat qualitatively different but all are potentially directly or indirectly affected by the degree of decentralization of government functions. For instance, greater decentralization would increase transparency and foster greater trust between the public and government officials, but such proximity might foster corrupt relations or other abuses of government power. Some taxes are levied and administered by local governments, whereas most business licenses and permits (e.g., liquor licenses for restaurants) are conferred by local governments. Another important distinction is that whereas business licenses may be procured by (new licenses) potential entrants or (recurring licenses) by existing firms, taxes are paid by existing firms. This differences relates to the age of firms and could affect their perceptions of government performance - existing firms are likely to have a better perspective having dealt with the full spectrum of government services.

The formal analysis will examine the strength of these relative perceptions with regard to

\footnotetext{
5 Thus, Enterprises Surveys Indicator Description ESID (2015), August 2015 version writes "Uniform universe, uniform methodology of implementation, and a core questionnaire are the basis of the Global methodology under which most Enterprise Surveys have been implemented since 2006" (p.2).

${ }^{6}$ The complete description of indicators covered in the survey is given in ESID. The World Enterprise Survey Questionnaire Note provides details about the questions posed to the managers. These and the other survey modules related to the methodology of the Enterprise Surveys are available at http://www.enterprisesurveys.org/methodology). The Business-Government relations subsection ' $j .30$ ' covers eight dimensions of firms' interaction with the government and its officials. From these eight aspects, this paper focuses on two, namely, tax administration, and business licensing and permits. The reasons for selecting these aspects are their importance in the link between business environment and governance, and to keep the analysis manageable. ${ }^{7}$ This is evidently not a comprehensive consideration of government performance, which is multidimensional. For instance, Guccio et al. (2014) examine whether local governments had better on time performance in executing public works projects in Italy.
} 
different aspects of government decentralization. To our knowledge, this aspect and the scope of analysis (in terms of number of nations and the number of respondents) have not been previously considered in the literature.

Alternate Perspectives on Decentralization: Four measures of decentralization are considered in this analysis:

- Fiscal Decentralization (FiscalDecent): As noted above, the consequences of decentralization have been most often analyzed in the literature from the perspective of the degree of fiscal autonomy of subnational units of government. This has been evaluated in a number of ways, including (i) local government expenditure share of overall government expenditures, (ii) subnational tax share, and (iii) local share of total government employment (Nelson (2013)). For the purposes of this analysis we selected the former - expenditure share - as our "baseline" decentralization measure. There is considerable variation among nations with respect to this decentralization measure. For instance, FiscalDecent has the maximum value of 0.55 for Uzbekistan. The minimum value of the variable is 0 for Mozambique and Suriname.

- Federalist System of Government (Federalist): In a federalist state, political power is split in some fashion between the central government and subnational (e.g., state, local governments) authorities. Generally, the constitution assigns the duties, rights, and privileges of each level of government. A dichotomous indicator is used here that takes on a value of one if the state is classified as "federal" by Elazar (1995) and zero otherwise. See Nelson (2013) for a summary of the extant literature that has employed such a measure as a decentralization indicator in analyzing corrupt activity by government officials. ${ }^{8}$ Fifteen percent of the countries in our sample were classified as federalist (Table 1).

- Aggregate Decentralization Index (AggDecent): This is a comprehensive measure of the importance and authority of local government offered by Ivanyna and Shah (2014). The index starts with the fiscal decentralization measure, referenced above (calculated using expenditure share). It then adjusts it for a number of institutional factors that are important when assessing the actual authority and independence of decision making by local authorities. These factors include (1) the security of the existence of local governments, (2) local expenditure, tax, and borrowing autonomy, (3) home rule for selfgovernance, and (4) local government control regarding, hiring, firing, and other human resource policies of their own employees. The value of the index ranged from a high of 20.71 for Sweden and a minimum value of 0 for Mozambique, with higher values

\footnotetext{
${ }^{8}$ Voigt and Blume (2012) note the shortcomings with capturing Federalism via a dichotomous variable. Also, see Treisman (2006).
} 
implying a larger size local sector relative to the central government and more authority in decision making.

- Administrative Decentralization Index (AdminDecent): This index is one of the component parts of the Aggregate Decentralization Index that focuses on local government control regarding, hiring, firing, and other human resource policies of their own employees. The construction of the index considers the local government share of total public-sector employment and an indicator of local government discretion related to employment and setting the terms of that employment (Ivanyna and Shah (2014)). Relatively speaking, this index captures contract enforcement freedom at the local level and this could have interesting outcomes in terms of ensuring government performance. ${ }^{9}$

In this data set, the value of AdminDecent varies from 0.9 (Sweden) to 0 (Mali, Mozambique, and Suriname), with larger values implying greater decentralization. The correlation between this index and the more encompassing aggregate decentralization is 0.67 .

We now turn to a discussion of the model setup and estimation strategy.

\section{MODEL, DATA AND ESTIMATION}

\subsection{Model}

Based on the above background and to focus on the objectives of this paper, the estimated relation takes government performance to be a function of decentralization, economic prosperity, institutions, country size and social factors. The main interest, however, is in the decentralization-performance nexus across the various dimensions of each considered. Thus, an equation of the following general form is estimated (with subscript $i$ denoting a country and $j$ denoting a survey response):

Perceived government performance ${ }_{i, j, g}=f\left(\right.$ Government decentralization $_{i, k}$, Economic Prosperity $\left(\mathrm{GDP}_{i}\right), \mathrm{Z}_{i w}$, Industry type $i j$, Firm Size $\left._{i j}\right)$

$$
\begin{aligned}
& \text { where } \\
& g=\text { TaxAdmin, BusLicense } \\
& k=\text { FiscalDecent, Federalism, AggDecent, AdmDecent } \\
& w=\text { GovtSize, RuleLaw, POP, Protestant }
\end{aligned}
$$

\footnotetext{
${ }^{9}$ Thus, in contrast to, say, fiscal decentralization, this index considers employment and administrative aspects, but not necessarily freedom regarding related budget allocations.
} 
The dependent variable in the model is alternatively entered as one of the two areas of perceived government performance drawn from the WES survey. As explained above, for each area, firm responses in the original WES survey are reclassified into one of three categories depending upon whether the respondent saw that area of government activity as a minor, moderate, or major impediment to their business operations. We report results for "major" and "minor" responses, while keeping "moderate" as the default.

The main explanatory variables are one of the four variables capturing various sizes and scopes of government decentralization discussed in the preceding section. In this model setup we also control for economic prosperity, industry type (by including a dummy variable for service industry (ServiceIND)), ${ }^{10}$ and for other county attributes, including government size (GovtSize), country size $(P O P)$, institutional quality (RuleLaw), and religion (Protestant - accounting for social influences). More prosperous nations generally have better government machinery, and performance of government services, while service industries may perceive government performance differently from respondents in other industries. A more direct aspect of institutional quality is considered by including an index for the Rule of Law (RuleLaw), whereby nations with better institutional quality are likely to perform better, ceteris paribus. The inclusion of government size and country size account for varying constraints and opportunities nations and governments of different sizes face in providing services.

We also consider the role of firm size in perceptions of government performance (Section 5.5). Large firms might have greater interactions with the government because they might require extra licenses and permits based on size and carry more political weight within the local community. Further, they might appear more easily on the radars of government inspectors and thus face greater scrutiny. Conversely, large firms might be more adept at dealing with the government because of their ability to hire specialists (although internal bureaucracies might make them somewhat lethargic (the "X-inefficiency" view).

Service industries are qualitatively different from other industries in some respects that might affect their interactions with the government and consequently, their perceptions of government performance. For instance, many service industries classified in the WES survey, such as banking and IT, might not require pollution permits (taxes) as their manufacturing counterparts, but might offer numerous different services that might require multiple types of regulations (e.g., the financial services firms). Forty two percent of firms in our sample belonged to the service sector (Table 1). Finally, the social dimension is accounted for by including consideration for the Protestant religion. Nations with majority of Protestants are perceived to have a stronger work ethic. Details about these variables are provided in Table 1.

\footnotetext{
${ }^{10}$ Our cross-country sample did have information on other industries. Our choice of controlling only for the service industries was dictated by the fact that this set of industries was qualitatively more distinct from others (e.g., manufacturing, construction, etc.).
} 


\subsection{Estimation}

Given that the firms' responses follow logical ordering (see Section 3), the ordered logit model is the natural choice (see Maddala (1986)). Thus, firm $i$ 's response $m$ can assume one of the three permissible values such as $m=1,2,3$. The responses are ordered such that higher $m$ values indicate "bad outcome" in terms of business-government relations. For instance, a firm with $m=1$ is facing minor obstacles in business routines caused by the government's rules, regulations, and their implementation, but a firm choosing alternative 3 is facing severe obstacles in firmgovernment relations. For a more focused comparison, we report results for only these two extreme outcomes and do so in the form of the marginal effects for each predictor. The marginal effects tell us the impact of each of the explanatory variable on the probability that a firm chooses alternative $m$.

\subsection{Data}

The large survey sample across countries was not completely uniform and we had to make some adjustments for the analysis. First, the time dimension of the variables is not uniform. For dependent variables (survey responses) the time varies from 2006 to 2015. In contrast, for decentralization measures, taken from Ivanyna and Shah (2014), the time dimension pertains to the 2000s and the values are fixed over time. The set of control variables are also for 2006 and remain invariant over time. Importantly, the choice of the period from 2006 to 2015 for the dependent variables and 2006 only for the right hand side variables helps to mitigate the problem of endogeneity.

Although the methodology used to cover the universe of the survey is consistent, the sample of firms surveyed, and the sample of countries in any year, is not the same over the years. For instance, in the year 2006 the total number of firms surveyed was 14,903 whereas in the year 2009 the number was 18,784. Similar differences exist for other years. It implies that we cannot call our data set 'a single panel of firms over time'. In other words, the data structure is not suitable for panel data methods. Nonetheless, the virtues associated with simplicity can save us from weaknesses associated with complex methods. As explained below, by controlling for the various macroeconomic and other institutional heterogeneities we can manage to extract reasonable inferences. Details about the variables used along with summary statistics are provided in Table 1.

\section{RESULTS}

In this section the results from estimating the model are reported for the various decentralization measures. Of primary interest is the effect that each decentralization measure has on survey responses to the question of how government affects their business operations. Two areas are addressed: tax administration, and business licensing and permits. Each of these can be thought 
of as a relevant area to assess the quality of government operations from a business person's perspective. For ease of comparison and interpretation, the marginal effect for each variable is displayed based upon the assumption that the other variables in the model are at their sample mean values. In each table the left-hand columns display estimates of how changes in the decentralization measure or one of the other control variables will affect the probability that the survey respondent will see the factor listed in the column heading as either a "minor" or "no obstacle" to their business operations. Right-hand columns pertain to the likelihood of survey response of either "major" or "very severe obstacle" impact on business operations. ${ }^{11}$

\subsection{Effects of Fiscal Decentralization (FiscalDecent)}

Table 2 reports the results using the local government's share of total government expenditures to measure decentralization. As discussed above, this indicator has often been used in earlier empirical work analyzing various decentralization topics, but with well-known deficiencies (Ebel and Yilmaz (2003)). The results in the present case show that survey respondents are less likely to see any of the two government areas as a serious detriment to business operation in countries with greater local autonomy when measured by expenditure decentralization. In each case, the parameter estimate on the FiscalDecent variable is statistically significant at the 99 percent level. These findings about the effect of fiscal decentralization can be seen in line with Feld and Schnellenbach (2011) where they found such decentralization to be positively impacting overall productivity. Further, Adam et al. (2014) used OECD data between 1970 and 2000 to examine the impact of fiscal decentralization on public sector efficiency in delivering education and health services. They found an inverted U-shaped relationship between government efficiency and fiscal decentralization, whereby initially greater fiscal decentralization increased efficiency in the sectors considered.

Turning briefly to the results for the control variables in the model the estimates are generally consistent across all three areas of government activity when judged by the sign of the parameter estimate and its statistical significance. As expected, the probability of more positive assessment of government outcomes is observed for countries with a stronger rule of law institutions and Protestant traditions. In contrast, larger government size (in terms of share of GDP), is associated with greater likelihood of a negative assessment of the impact of government on business operations in all three areas. However, in countries with higher incomes, survey respondents are also more likely to have a more negative assessment of the government outcomes in all cases. In terms of magnitudes, the estimates imply that, other things equal, with a one standard deviation increase in per capita GDP from the sample mean the probability that a business manager would agree that business licensing matters are at most only minor obstacle to business operations would decrease by $4 \%$ to $5 \%$ for tax administration, and business licensing.

\footnotetext{
${ }^{11}$ Marginal effects for the remaining response option - "moderate" obstacle - are not reported to conserve space.
} 
In more populous countries business managers tend to have a more negative assessment of government performance. In contrast, respondents from service industries are more likely to have a positive assessment of decentralization in all areas. This finding is consistent with the view that certain regulation or taxes such as those related to pollution are not widely imposed on many service industries, decreasing their interactions with the government and thereby enhancing their views of government performance.

\subsection{Effects of Federalism (Federalism)}

Another way to view decentralization is to distinguish between federalist and unitary states. In the latter the central government holds most of the power and local regional governments - to the extent they exist - are administrative units of the national government. Fifteen percent of the countries in this data set are classified as federalist states.

Table 3 presents the results using a binary federalist state decentralization indicator along with the same control variables used earlier. Interestingly, the findings are just the opposite of what was found relative to the fiscal decentralization measure. In particular, relative to unitary states, federalist governments perform worse in both areas considered. For example, in a federalist state the probability that a business manager would consider tax administration to be either no obstacle or only a minor obstacle to business operations decreases by over $14 \%$, other things equal, based on the estimate reported in column 3.1a of the table. For the business licensing area of government it decreases by nearly $12 \%$ (column $3.2 \mathrm{a}$ ).

As to the control variables, the impact of the Protestant ethic, government size, and the service industry variables are similar to those in Table 2 . The evidence for the remaining variables in the model including the rule of law, GDP, and population variables is mixed in terms of the effect on business manager assessment of government performance in the areas considered.

\subsection{Effects of Aggregate Decentralization (AggDecent)}

Table 4 presents the results when Ivanyna and Shah's (2014) Aggregate Decentralization Index is used as the decentralization measure. This measure adjusts the expenditure decentralization indicator (FiscalDecent) through the incorporation of several other important institutional factors that are relevant in assessing the autonomy of local governments. These factors include indicators of expenditure and tax autonomy, the security of existence of local governments, and variables that measure political and administrative decentralization within a country.

With these adjustments a different story emerges from what is reported in Table 2 as to how decentralization affects manager view on the impact of the two areas of government activity on their business operations. A positive assessment still remains regarding business licensing. The parameter estimates are statistically significant at the $99 \%$ level in each case, but the magnitudes

of the parameter estimates are modest. For example, if a county currently at the sample mean for 
AggDecent in this data set $(=1.5)$ were to change its institutions such that its decentralization score increased to match Brazil $(=8.1)$, the highest index value in the data set used for this analysis, other things equal, the probability that a business manager would agree that business licensing matters are at most only a minor obstacle to business operations would increase by just $5 \%$.

Regarding the other area of government activity, the evidence indicates that the indicator of decentralization has no statistically significant effect in the tax administration area (columns 4.1a and 4.1b).

For the most part, the findings for the control variables are consistent with what is noted in Table 2. Countries with more effective rule of law and Protestant-dominated populations tend to have better outcomes, while nations that are more affluent and with a larger overall public sector tend to be viewed more negatively. Once again, the evidence for the population variable is mixed.

\subsection{Effects of Administrative decentralization (AdminDecent)}

The last decentralization measure considered is more narrowly focused than the others and is labelled as administrative decentralization. It reflects the local government share of all public sector employment and with the degree to which there is local control in hiring policies of these employees. Higher values of AdminDecent imply that local employees are relatively more important in delivering public services and that there is more local control over who these employees are.

Table 5 summarizes the results and shows that administrative decentralization is statistically significant at conventional levels for all areas. In each case the analysis reveals greater decentralization is associated with better manager assessment regarding how government affects their business operations. The largest impacts are in the business licensing and operations area (columns 5.2a and 5.2b), activities that are most likely to lie within the purview of the local public sector. In particular, if a county currently at the sample mean for AdminDecent in this data set $(=0.35)$ were to change its institutions such that its decentralization score increased to match the highest value in the data set $(=0.82)$, other things equal, the probability that a business manager would agree that business licensing matters are at most only a minor obstacle to business operations would increase by $5 \%$. The finding is consistent with arguments dating back to Oates (1972) and earlier that local officials are more accountable to the citizens they serve as they are disciplined by inter-jurisdictional competition for mobile resources. Moreover, authorities are subject to "yardstick evaluation" as their performance can be more easily compared to officials in similar positions in neighboring jurisdictions. The findings for the control variables in each model generally mirror earlier results.

\subsection{Additional considerations: Effects of firm size}


To obtain additional insights and to better exploit the information available in the survey, we included a dummy variable, (LargeFirm), identifying respondents from large firms. Large firms were classified as firms with more than 100 employees and they formed nineteen percent of our sample (see Table 1).

The size of firms relates to firm vintage discussed above. Large firms are likely to be old and established (unless they grow big by mergers and acquisitions) and thus likely to have a more involved view of government performance than new firms.

Re-estimating Tables 2-5 with LargeFirm as an additional regressor provided some interesting results. ${ }^{12}$ Large firms consistently viewed tax administration to be a severe impediment to their business operations across the four dimensions of government decentralization considered. This result is consistent with the view that large firms, either due to their size or longevity (or both), are likely to have rather involved interactions with tax authorities and they view such interactions unfavorably (as opposed to small or new firms who might not have enough earnings to be caught in the tax net). The findings for the decentralization variables were unchanged by the inclusion of LargeFirm in the model.

\subsection{Relative magnitudes of impacts}

To obtain quantitative comparisons, Table 6 presents a side-by-side direct comparison of the impacts of greater decentralization using the estimates presented in Tables 2-5. For each decentralization measure the entries in the table show how greater decentralization affects the probability that business managers will respond that the government activity in question is either a minor or no obstacle to business operations. For all four measures greater decentralization is defined here as a one standard deviation increase in the decentralization measure above the sample mean.

The first takeaway from this comparison is that how decentralization is measured affects business perceptions of government performance matters. Measured either by local government expenditure share or a federalist binary variable, relatively sizable effects from greater decentralization are observed, but in opposite directions - as can be seen by comparing the first two rows of Table 6. Of course, neither measure addresses the institutional details as to how much actual authority rests with lower tiers of government and this may affect the results. Our findings confirm that this is an important consideration. In particular, the aggregate decentralization measure attempts to account for these details and when this is done (row three of the table) the evidence reveals that the impacts of greater decentralization only has a modest positive impact on managerial assessment of government performance in one of the two areas considered and no statistically significant effect in the second area (tax administration).

\footnotetext{
${ }^{12}$ These results are not reported but are available upon request.
} 
The second takeaway from this analysis is that greater administrative decentralization would appear to hold out the most hope to get business managers to improve their assessment of government performance as shown by the results summarized in the last row of the table. The improved perceptions are the largest in the business licensing area (2.4\%) based on the above analysis. Viewed from a somewhat different perspective, 30 countries in the data set have a zero value for the administrative decentralization index. If these countries were to adopt policies to take them to the sample mean in the data set, the improved perception in the business licensing area would be nearly $5 \%$. These results should not be surprising as licensing is typically under the purview of government officials at the local level. The concluding section follows.

\section{CONCLUSIONS}

The degree and scope of decentralization of government services continues to intrigue policymakers in their quest to conserve resources and improve the delivery of government services. The elusive goal of an "optimal" level of decentralization has kept researchers engaged with an examination of causes and effects of government decentralization with varying methodologies and data. ${ }^{13}$ This paper adds to the literature by using data on firm's perceptions of government performance and examining the effect of various forms of decentralization on such performance.

The analysis presented in this paper can be distinguished from the literature on the effects of government decentralization on quality of governance in several important ways. First, our focus has been business managers and their perceptions about how various government policies in the areas of tax policy and business licensing affects their operations. Second, we have employed a large micro data set spanning a wide cross-section of countries, thereby mitigating the potential for two-way link between government performance and the extent to which government is close to the citizens it serves. Third, the decentralization measures considered control for key institutional factors that may affect how much control local governments actually have relative to the central government in delivering public services.

Tying to the questions posed in the introduction we have found that how decentralization is measured is important when assessing its impact on government performance, at least in the context of how government affects business operations. In particular, greater decentralization, comprehensively measured to control for institutional differences across countries, has only a modest positive effect on business manager assessment of government performance.

The strongest evidence in favor of a positive linkage is in the area of administrative decentralization relative to business licensing. Delivering government services and administering such activities with local employees, subject to employment and HR policies that

\footnotetext{
${ }^{13}$ An added issue concerns the difficulties with implementing decentralization as noted by Shah and Thompson (2004).
} 
are locally controlled, leads to a moderate, but not inconsequential improvement in business perception of how well government functions. A large group of developing countries has plenty of room to make policy changes in this area as there presently exists little or no local government employment in these countries, and to the extent there is, the terms of such employment still rests with the central authority. One policy implication is that the move towards decentralization would not necessarily result in positive outcomes about government performance and need to be qualified with regard to decentralization type and the type of performance being measured. 


\section{REFERENCES}

Adam, A., M.D. Delis and P. Kammas, 2014, "Fiscal decentralization and public sector efficiency: Evidence from OECD countries", Economics of Governance, 15:17-49.

Besley, T.J. and S. Coate, 2003, "Centralized versus decentralized provision of local public goods: A political economy approach”, Journal of Public Economics, 87(12): 2611-2637.

Blume, L. and S. Voigt, 2011, "Federalism and decentralization: A critical survey of frequently used indicators", Constitutional Political Economy, 22(3): 238-264.

Brueckner, J.K., 2003, "Strategic interaction among governments: An overview of empirical studies", International Regional Science Review, 26(2): 175-188.

Ebel, R.D. and S. Yilmaz, 2003, “On the measurement and impact of fiscal decentralization”, In: J. Martinez-Vazquez and J. Alm (eds.), Public Finance in Developing and Transitional Countries: Essays in Honor of Richard Bird, Cheltenham, UK: Edward Elgar, pp. 101-126.

Elazar, D.J., 1995, “From statism to federalism: A paradigm shift”, Publius, 25(2): 5-18.

Faguet, J.-P., 2014, “Decentralization and governance”, World Development, 53: 2-13.

Fan, C.S., C. Lin and D. Treisman, 2009, "Political decentralization and corruption: Evidence from around the world", Journal of Public Economics, 93:14-34.

Feld, L.P. and J. Schnellenbach, 2011, "Fiscal federalism and long-run macroeconomic performance: A survey of recent research", Environment and Planning C: Government and Policy 29(2): 224-243.

Fisman, R. and R. Gatti, 2002, "Decentralization and corruption: Evidence across countries", Journal of Public Economics, 83(3): 325-345.

Goel, R.K. and M.A. Nelson, 2011, "Government fragmentation versus fiscal decentralization and corruption", Public Choice, 148(3-4): 471-490.

Goel, R.K. and J.W. Saunoris, 2015, "Virtual versus physical government decentralization: Effects on corruption and the shadow economy", Public Budgeting \& Finance, forthcoming.

Guccio, C., G. Pignataro and I. Rizzo, 2014, "Do local governments do it better? Analysis of time performance in the execution of public works", European Journal of Political Economy, 34, 237-252.

Hallward-Driemeier, M. and L. Pritchett, 2015, "How business is done in the developing world: Deals versus rules", Journal of Economic Perspectives, 29(3): 121-140.

International Monetary Fund, 2009, Macro Policy Lessons for a Sound Design of Fiscal Decentralization, Washington, DC: International Monetary Fund. 
Ivanyna, M. and A. Shah, 2014, "How close is your government to its people? Worldwide indicators on localization and decentralization", Economics: The Open-Access, OpenAssessment E-Journal, http://dx.doi.org/10.5018/economics-ejournal.ja.2014-3

Knack, S. and P. Keefer, 1995, "Institutions and economic performance: Cross-country tests using alternative institutional measures”, Economics \& Politics, 7(3): 207-227.

Kyriacou, A.P. and O. Roca-Sagalés, 2011a, "Fiscal decentralization and government quality in the OECD", Economics Letters, 111: 191-193.

Kyriacou, A.P. and O. Roca-Sagalés, 2011b, "Fiscal and political decentralization and government quality”, Environment and Planning C Government and Policy, 29(2): 204-223.

La Porta, R., F. Lopez-de-Silanes, A.Shleifer and R.Vishny, 1999, "The quality of government", Journal of Law, Economics, and Organization, 15(1): 222-279.

Lago-Peñas, I., S. Lago-Peñas, and J. Martinez-Vazquez, 2011, "The political and economic consequences of decentralization", Environment and Planning C: Government and Policy, 29: 197-203.

Maddala, G.S., 1986, Limited-Dependent and Qualitative Variables in Econometrics, Cambridge: Cambridge University Press.

Martinez-Vazquez, J., S. Lago-Peñas and A. Sacchi, 2015, “The impact of fiscal decentralization: A survey”, GEN - Governance and Economics Research Network, GEN Working Paper A 2015 - 5, webs.uvigo.es/infogen/WP.

Nelson, M.A., 2013, “Corruption and the size of local governments: Are they related?" in S. Lago-Peñas and J. Martinez-Vazquez, (eds.), The Challenge of Local Government Size: Theoretical Perspectives, International Experience, and Policy Reform. Northampton, MA: Edward Elgar, pp. 87-124.

Oates, W., 1972, Fiscal Federalism, New York: Harcourt Brace Jovanovich.

Panizza, U., 1999, "On the determinants of fiscal centralization: Theory and evidence”, Journal of Public Economics, 74(1): 97-139.

Prud'homme, R., 1995, “The dangers of decentralization”, World Bank Research Observer, 10(2): 201-220.

Rodden, J., 2004, "Comparative federalism and decentralization: On meaning and measurement”, Comparative Politics, 36(4): 481-500. 
Rodríguez-Pose, A. and R. Ezcurra, 2011, "Is fiscal decentralization harmful for economic growth? Evidence from the OECD countries”, Journal of Economic Geography, 11(4): 619-643.

Rodriguez-Pose, A. and N. Gill, 2003, "The global trend towards devolution and its implications”, Environment and Planning C: Governance and Policy, 21(3): 333-351.

Shah, A. and T. Thompson, 2004, "Implementing decentralized local governance: A treacherous road with potholes, detours and road closures”, World Bank Policy Research Working Paper \# 3353, June.

Stegarescu, D., 2005, "Public sector decentralization: Measurement concepts and recent international trends", Fiscal Studies, 26(3): 301-333.

Treisman, D., 2006, "Fiscal decentralization, governance, and economic performance: A reconsideration", Economics \& Politics, 18(2): 219-235.

United Nations. 2009. International Guidelines on Decentralization and Access to Basic Services for All. Nairobi: UN-HABITAT.

Voigt, S. and L. Blume, 2012, "The economic effects of federalism and decentralization: A cross-country assessment”, Public Choice, 151(1): 229-254.

World Bank, 1999, "Decentralization: Rethinking government", Entering the 21st Century: World Development Report 1999/2000, New York: Oxford University Press, 107-124.

Yeung, R., 2009, "The effects of fiscal decentralization on the size of government: A metaanalysis," Public Budgeting \& Finance, 29(4): 1-23. 


\begin{tabular}{|c|c|c|}
\hline Variable & Definition; Mean, SD & Source \\
\hline TaxAdmin & $\begin{array}{l}\text { An ordered response to the question asking how far tax } \\
\text { administration issues affect business operations. The } \\
\text { response ranges from } 0 \text { (no obstacle) to } 4 \text { (very severe } \\
\text { obstacle) - see Table A } 1 ; 1.56,0.74 \text {. }\end{array}$ & $\begin{array}{l}\text { World Bank World Enterprise } \\
\text { Surveys. World Bank. } \\
\text { (www.enterprisesurveys.org) }\end{array}$ \\
\hline BusLicense & $\begin{array}{c}\text { An ordered response to the question asking how far business } \\
\text { permits and licensing issues affect business operations. The } \\
\text { response ranges from } 0 \text { (no obstacle) to } 4 \text { (very severe } \\
\text { obstacle) - see Table A } 1 ; 1.47,0.73 \text {. }\end{array}$ & $\begin{array}{l}\text { World Bank World Enterprise } \\
\text { Surveys. World Bank. } \\
\text { (www.enterprisesurveys.org) }\end{array}$ \\
\hline FiscalDecent & $\begin{array}{c}\text { Fiscal decentralization. Local government expenditures as } \\
\text { percentage of general government expenditures. Higher } \\
\text { values indicate greater fiscal decentralization; } 0.15,0.13\end{array}$ & Ivanyna and Shah (2014) \\
\hline Federalism & $\begin{array}{l}\text { Binary variable indicator of a country classified as federalist; } \\
\qquad 0.15,0.36 \text {. }\end{array}$ & Treisman (2006) \\
\hline AggDecent & $\begin{array}{c}\text { Aggregate decentralization. Index incorporates the relative } \\
\text { importance of local government (measured by expenditure } \\
\text { decentralization), the security of existence of local } \\
\text { government, and fiscal, political decentralization and } \\
\text { administrative decentralization indexes; Range: } 0-34 \text {, with } \\
\text { higher values implying greater aggregate decentralization; } \\
1.53,2.32 \text {. }\end{array}$ & Ivanyna and Shah (2014) \\
\hline AdminDecent & $\begin{array}{l}\text { Administrative decentralization. Index measures the ability } \\
\text { of local governments to hire and fire and set terms of } \\
\text { employment of local employees as well as regulatory control } \\
\text { over own functions; Range: } 0-1 \text {, with higher values implying } \\
\text { greater administrative decentralization; } 0.35,0.23 \text {. }\end{array}$ & Ivanyna and Shah (2014) \\
\hline RuleLaw & $\begin{array}{l}\text { Rule of law index. It captures perceptions of the extent to } \\
\text { which agents have confidence in and abide by the rules of } \\
\text { society, and in particular the quality of contract } \\
\text { enforcement, property rights, the police, and the courts, as } \\
\text { well as the likelihood of crime and violence; Range: }-2.5 \text { to } \\
+2.5 \text {, with higher values denoting stronger institutions; }-0.41 \text {, } \\
0.67 \text {. }\end{array}$ & $\begin{array}{l}\text { Kaufmann and Kraay (2014) } \\
\text { http://info.worldbank.org/governanc } \\
\text { e/wgi/index.aspx\#home }\end{array}$ \\
\hline Protestant & $\begin{array}{c}\text { Dummy variable that assumes a value of } 1 \text { if percentage of } \\
\text { population professing Protestant faith exceeds } 50 \text { percent, } \\
\text { otherwise zero; } 0.03,0.16\end{array}$ & La Porta et al. (1999) \\
\hline$G D P$ & $\begin{array}{l}\text { Log of GDP per capita in constant } 2005 \text { US dollars; } 7.45 \text {, } \\
1.14 .\end{array}$ & $\begin{array}{l}\begin{array}{l}\text { World Development Indicators } \\
\text { (http://data.worldbank.org/indicator }\end{array} \\
\text { /NY.GDP.PCAP.KD?page }=2 \text { ) }\end{array}$ \\
\hline GovtSize & $\begin{array}{l}\text { General government final consumption expenditure (\% of } \\
\text { GDP); } 13.18,4.87 .\end{array}$ & $\begin{array}{c}\begin{array}{c}\text { World Development Indicators } \\
\text { http://data.worldbank.org/indicator/ }\end{array} \\
\text { NE.CON.GOVT.ZS }\end{array}$ \\
\hline POP & Log of country's population; $17.24,1.94$. & $\begin{array}{c}\begin{array}{c}\text { World Development Indicators } \\
\text { (http://data.worldbank.org/indicator }\end{array} \\
\text { /SP.POP.TOTL ) }\end{array}$ \\
\hline ServiceIND & $\begin{array}{c}\text { A categorical variable representing firms belonging to } \\
\text { services sector. It includes sectors like construction, hotels } \\
\text { and restaurants, IT and IT services, retail, tourism, transport, } \\
\text { wholesale etc.; } 0.42,0.49 \text {. }\end{array}$ & $\begin{array}{l}\text { World Bank World Enterprise } \\
\text { Surveys. World Bank. } \\
\text { (www.enterprisesurveys.org) }\end{array}$ \\
\hline LargeFirm & $\begin{array}{l}\text { A categorical variable representing firms with } 100 \text { or more } \\
\text { employees; } 0.19,0.39 .\end{array}$ & $\begin{array}{c}\text { World Bank World Enterprise } \\
\text { Surveys. World Bank. } \\
\text { (www.enterprisesurveys.org) }\end{array}$ \\
\hline
\end{tabular}




\begin{tabular}{|c|c|c|c|c|}
\hline $\begin{array}{l}\text { Dep. variable } \\
\rightarrow\end{array}$ & $\begin{array}{c}\text { (2.1a) } \\
\text { TaxAdmin }\end{array}$ & $\begin{array}{c}\text { (2.1b) } \\
\text { TaxAdmin }\end{array}$ & $\begin{array}{c}\text { (2.2a) } \\
\text { BusLicense }\end{array}$ & $\begin{array}{c}\text { (2.2b) } \\
\text { BusLicense }\end{array}$ \\
\hline FiscalDecent & $\begin{array}{c}0.459 * * * \\
(0.014)\end{array}$ & $-0.239 * * *$ & $0.440 * * *$ & $-0.235 * * *$ \\
\hline RuleLaw & $\begin{array}{c}0.095 * * * \\
(0.003)\end{array}$ & $\begin{array}{c}-0.050 * * * \\
(0.002)\end{array}$ & $\begin{array}{c}0.105 * * * \\
(0.003)\end{array}$ & $\begin{array}{c}-0.056 * * * \\
(0.002)\end{array}$ \\
\hline Protestant & $\begin{array}{c}0.186 * * * \\
(0.014)\end{array}$ & $\begin{array}{c}-0.097 * * * \\
(0.007)\end{array}$ & $\begin{array}{c}0.172 * * * \\
(0.013)\end{array}$ & $\begin{array}{c}-0.092 * * * \\
(0.007)\end{array}$ \\
\hline$G D P$ & $\begin{array}{c}-0.043 * * * \\
(0.002)\end{array}$ & $\begin{array}{c}0.022 * * * \\
(0.001)\end{array}$ & $\begin{array}{c}-0.039 * * * \\
(0.002)\end{array}$ & $\begin{array}{c}0.021 * * * \\
(0.001)\end{array}$ \\
\hline GovtSize & $\begin{array}{c}-0.003^{* * *} \\
(0.000)\end{array}$ & $\begin{array}{c}0.002 * * * \\
(0.000)\end{array}$ & $\begin{array}{c}-0.005^{* * * *} \\
(0.000)\end{array}$ & $\begin{array}{c}0.003 * * * \\
(0.000)\end{array}$ \\
\hline POP & $\begin{array}{c}-0.011 * * * \\
(0.001)\end{array}$ & $\begin{array}{c}0.006 * * * \\
(0.001)\end{array}$ & $\begin{array}{c}-0.013 * * * \\
(0.001)\end{array}$ & $\begin{array}{c}0.007 * * * \\
(0.001)\end{array}$ \\
\hline ServiceIND & $\begin{array}{c}0.022 * * * \\
(0.004)\end{array}$ & $\begin{array}{c}-0.011 * * * \\
(0.002)\end{array}$ & $\begin{array}{c}0.012 * * * \\
(0.003)\end{array}$ & $\begin{array}{c}-0.006 * * * \\
(0.002)\end{array}$ \\
\hline Observations & 77,360 & 77,360 & 82,448 & 82,448 \\
\hline \multicolumn{5}{|c|}{$\begin{array}{l}\text { Notes: See Table } 1 \text { for variable details. Delta-method standard errors in } \\
\text { parentheses; *** } p<0.01, * * p<0.05, * p<0.1 \text {. } \\
\text { Reported coefficients are marginal effects, based on ordered logit regressions (the } \\
\text { pseudo- } R^{2} s \text { for the underlying regressions are available upon request). All } \\
\text { predictors at their average value. Column header indicates the outcome factor. As } \\
\text { explained in the text, only two categories of firms' responses are considered: the } \\
\text { factor in question is a minor obstacle to firms' business operations, and factor in } \\
\text { question is a major obstacle to firms' business operations. }\end{array}$} \\
\hline
\end{tabular}




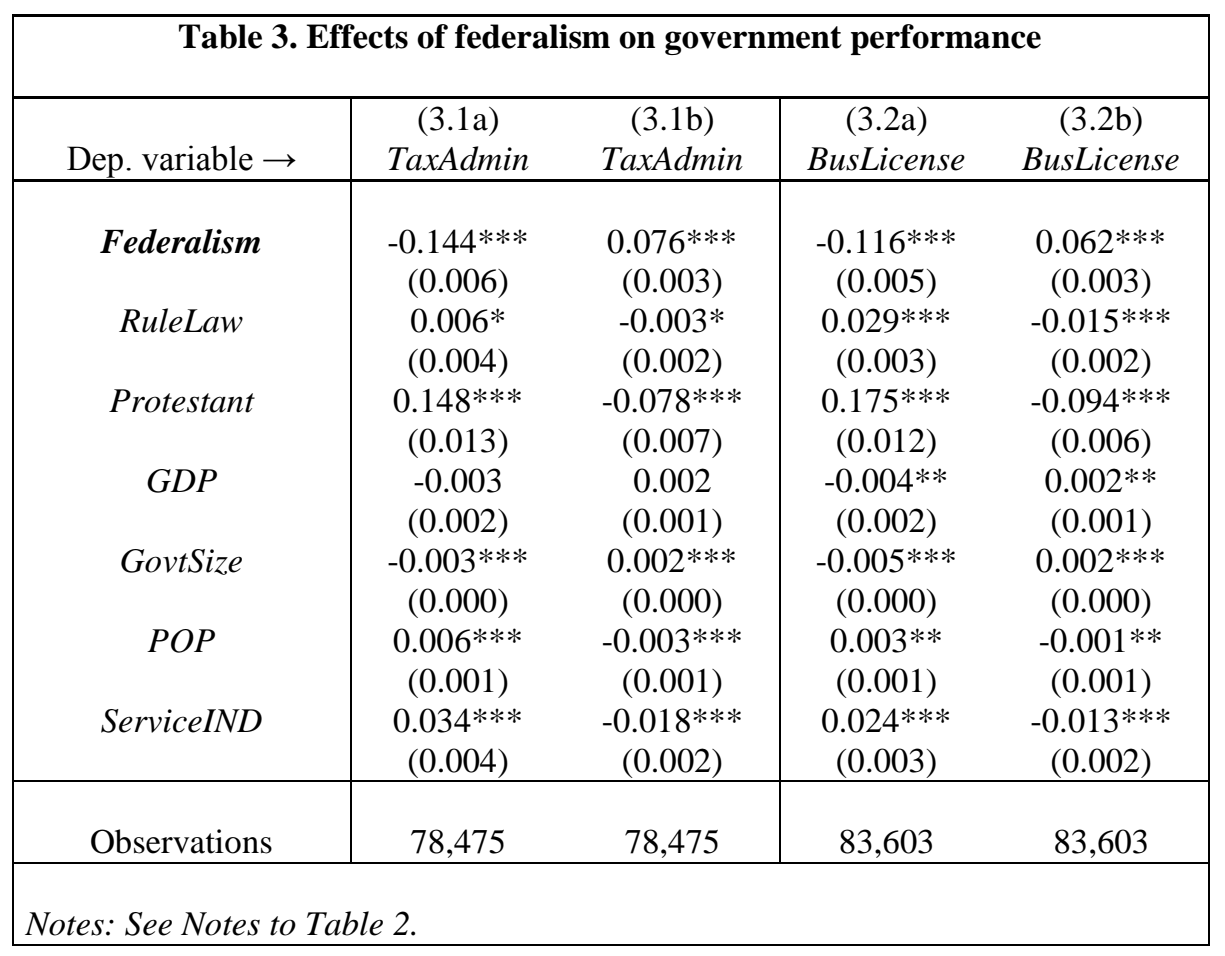




\begin{tabular}{|c|c|c|c|c|}
\hline Dep. variable $\rightarrow$ & $\begin{array}{c}\text { (4.1a) } \\
\text { TaxAdmin }\end{array}$ & $\begin{array}{c}(4.1 \mathrm{~b}) \\
\text { TaxAdmin } \\
\end{array}$ & $\begin{array}{c}(4.2 \mathrm{a}) \\
\text { BusLicense }\end{array}$ & $\begin{array}{c}\text { (4.2b) } \\
\text { BusLicense }\end{array}$ \\
\hline AggDecent & $\begin{array}{l}-0.001 \\
(0.001)\end{array}$ & $\begin{array}{c}0.001 \\
(0.001)\end{array}$ & $\begin{array}{c}0.008 * * * \\
(0.001)\end{array}$ & $\begin{array}{c}-0.004 * * * \\
(0.000)\end{array}$ \\
\hline RuleLaw & $\begin{array}{c}0.050 * * * \\
(0.003)\end{array}$ & $\begin{array}{c}-0.027 * * * \\
(0.002)\end{array}$ & $\begin{array}{c}0.071 * * * \\
(0.003)\end{array}$ & $\begin{array}{c}-0.038 * * * \\
(0.002)\end{array}$ \\
\hline Protestant & $\begin{array}{c}0.168 * * * \\
(0.014)\end{array}$ & $\begin{array}{c}-0.089 * * * \\
(0.007)\end{array}$ & $\begin{array}{c}0.162 * * * \\
(0.013)\end{array}$ & $\begin{array}{c}-0.087 * * * \\
(0.007)\end{array}$ \\
\hline$G D P$ & $\begin{array}{c}-0.027 * * * \\
(0.002)\end{array}$ & $\begin{array}{c}0.014 * * * \\
(0.001)\end{array}$ & $\begin{array}{c}-0.032 * * * \\
(0.002)\end{array}$ & $\begin{array}{c}0.017 * * * \\
(0.001)\end{array}$ \\
\hline GovtSize & $\begin{array}{l}-0.001 * \\
(0.000)\end{array}$ & $\begin{array}{l}0.000 * \\
(0.000)\end{array}$ & $\begin{array}{c}-0.005^{* * * *} \\
(0.000)\end{array}$ & $\begin{array}{c}0.002 * * * \\
(0.000)\end{array}$ \\
\hline POP & $\begin{array}{l}-0.001 \\
(0.001)\end{array}$ & $\begin{array}{c}0.000 \\
(0.001)\end{array}$ & $\begin{array}{c}-0.009 * * * \\
(0.001)\end{array}$ & $\begin{array}{c}0.005 * * * \\
(0.001)\end{array}$ \\
\hline ServiceIND & $\begin{array}{c}0.035 * * * \\
(0.004)\end{array}$ & $\begin{array}{c}-0.018 * * * \\
(0.002)\end{array}$ & $\begin{array}{c}0.024 * * * \\
(0.003)\end{array}$ & $\begin{array}{c}-0.013 * * * \\
(0.002)\end{array}$ \\
\hline Observations & 78,208 & 78,208 & 83,326 & 83,326 \\
\hline
\end{tabular}




\begin{tabular}{|c|c|c|c|c|}
\hline \multicolumn{5}{|c|}{$\begin{array}{c}\text { Table 5. Effects of administrative decentralization on government } \\
\text { performance }\end{array}$} \\
\hline Dep. variable $\rightarrow$ & $\begin{array}{c}\text { (5.1a) } \\
\text { TaxAdmin }\end{array}$ & $\begin{array}{c}(5.1 \mathrm{~b}) \\
\text { TaxAdmin }\end{array}$ & $\begin{array}{c}(5.2 \mathrm{a}) \\
\text { BusLicense }\end{array}$ & $\begin{array}{c}\text { (5.2b) } \\
\text { BusLicense }\end{array}$ \\
\hline AdminDecent & $0.048 * * *$ & $-0.025^{* * *}$ & $0.106 * * *$ & $-0.057 * * *$ \\
\hline RuleLaw & $0.051^{* * * *}$ & $-0.027 * * *$ & $0.065^{* * * *}$ & $\begin{array}{c}-0.035 * * * \\
(0.002)\end{array}$ \\
\hline Protestant & $\begin{array}{l}0.175^{* * * *} \\
(0.014)\end{array}$ & $\begin{array}{l}-0.093 * * * \\
(0.007)\end{array}$ & $\begin{array}{l}0.186 * * * \\
(0.012)\end{array}$ & $\begin{array}{l}-0.100 * * * \\
(0.007)\end{array}$ \\
\hline$G D P$ & $\begin{array}{c}-0.031 * * * \\
(0.002)\end{array}$ & $\begin{array}{c}0.016 * * * \\
(0.001)\end{array}$ & $\begin{array}{c}-0.032 * * * \\
(0.002)\end{array}$ & $\begin{array}{c}0.017 * * * \\
(0.001)\end{array}$ \\
\hline GovtSize & $\begin{array}{c}-0.001 * * * \\
(0.000)\end{array}$ & $\begin{array}{c}0.001 * * * \\
(0.000)\end{array}$ & $\begin{array}{c}-0.004 * * * \\
(0.000)\end{array}$ & $\begin{array}{c}0.002 * * * \\
(0.000)\end{array}$ \\
\hline POP & $\begin{array}{c}-0.003 * * \\
(0.001)\end{array}$ & $\begin{array}{c}0.001 * * \\
(0.001)\end{array}$ & $\begin{array}{c}-0.008 * * * \\
(0.001)\end{array}$ & $\begin{array}{c}0.004 * * * \\
(0.001)\end{array}$ \\
\hline ServiceIND & $\begin{array}{c}0.034 * * * \\
(0.004)\end{array}$ & $\begin{array}{c}-0.018 * * * \\
(0.002)\end{array}$ & $\begin{array}{c}0.024 * * * \\
(0.003)\end{array}$ & $\begin{array}{c}-0.013 * * * \\
(0.002)\end{array}$ \\
\hline Observations & 78,208 & 78,208 & 83,326 & 83,326 \\
\hline
\end{tabular}




\begin{tabular}{|c|c|c|}
\hline \multirow[b]{2}{*}{$\begin{array}{c}\text { Decentralization } \\
\text { measure } \downarrow\end{array}$} & \multicolumn{2}{|c|}{ Dimensions of government performance } \\
\hline & TaxAdmin & BusLicense \\
\hline FiscalDecent & $6.00 \%$ & $5.70 \%$ \\
\hline Federalism & $-5.20 \%$ & $-4.20 \%$ \\
\hline AggDecent & $*$ & $1.80 \%$ \\
\hline AdminDecent & $1.10 \%$ & $2.40 \%$ \\
\hline \multicolumn{3}{|c|}{$\begin{array}{l}\text { Notes: See Table } 1 \text { for variable details. The marginal effects show the effect of } \\
\text { one standard deviation increase in decentralization measure from mean value on } \\
\text { the probability that respondent will see the government activity as no more than } \\
\text { a minor obstacle to business operations. } \\
\text { (*) - hypotheses that decentralization has no effect cannot be rejected at } \\
\text { conventional levels of statistical significance. }\end{array}$} \\
\hline
\end{tabular}


Appendix. Table A1.

Reclassification of firms' responses in the original WES survey

\begin{tabular}{|c|c|c|c|c|c|}
\hline WES Scheme & No obstacle & Minor obstacle & $\begin{array}{c}\text { Moderate } \\
\text { obstacle }\end{array}$ & $\begin{array}{c}\text { Major obstacle severe } \\
\text { obstacle }\end{array}$ \\
\hline TaxAdmin & 0 & 1 & 2 & 3 & 4 \\
\hline BusLicense & 0 & 1 & 2 & 3 \\
\hline Modified scheme used & \multicolumn{2}{|c|}{ Minor obstacle } & $\begin{array}{c}\text { Moderate } \\
\text { obstacle }\end{array}$ & 3 \\
\hline TaxAdmin & 1 & 2 & 3 \\
\hline BusLicense & 1 & 2 & \\
\hline
\end{tabular}

